\title{
Mapping Bedrock Topography using Electromagnetic Profiling
}

\author{
UGWU, S. A.; EZE, C.L.
}

Department of Geology,University of Port Harcourt.ugwusa@yahoo.com Institute of Geosciences and Space Technology Rivers State University of Science and Technology, Port Harcourt

\begin{abstract}
ABSRACT: Electromagnetic profiling method was used in Echara Unuhu, within the Abakaliki Urban, to map the bedrock topography which also aids us to determine the position of the deepest fractured shale where a productive borehole will be constructed The area under study is within the Abakaliki Shales Geologic Formation. The rocks are packages of thinly layered olive green to dark gray blush black shale, which are frequently calcareous, subordinate fine-grained micaceous sandstone; micaceous siltstone, sandy shales and shelly limestone. Two-man portable Geonics EM 34-3 electromagnetic equipment was used in the profiling normal to the strike. The results show that typical conductivity value of the shallow bedrock $(1.51-2.0 \mathrm{~m})$ lies between $22.1-53.7 \mathrm{mmho} / \mathrm{m}$ while conductivity values from $269-786 \mathrm{mmohm} / \mathrm{m}$ indicate thicker/deeper $(25-30 \mathrm{~m})$ fractures with higher moisture contents. Mapping of bedrock topography at Echara Unuhu enabled us to locate a point which on drilling produces good water yield; this technique is recommended for use in formations with similar characteristics @ JASEM
\end{abstract}

Mapping of bedrock configuration is important both for civil engineering and hydrogeological purposes. In civil engineering it helps to determine the appropriate and safest depth to place the foundation of our buildings. .Hydrogeologically, especially in shale dominated environment, it helps for the thickness of fractures which is the target for groundwater development to be ascertained. Abakaliki Urban situates between latitudes $6^{\circ} 17-6^{\circ}$ $19^{\prime} \mathrm{N}$ and longitudes $8^{\circ} 04^{\prime}-8^{\circ} 06^{\prime} \mathrm{E}$ (Fig. 1) in the Benue trough.

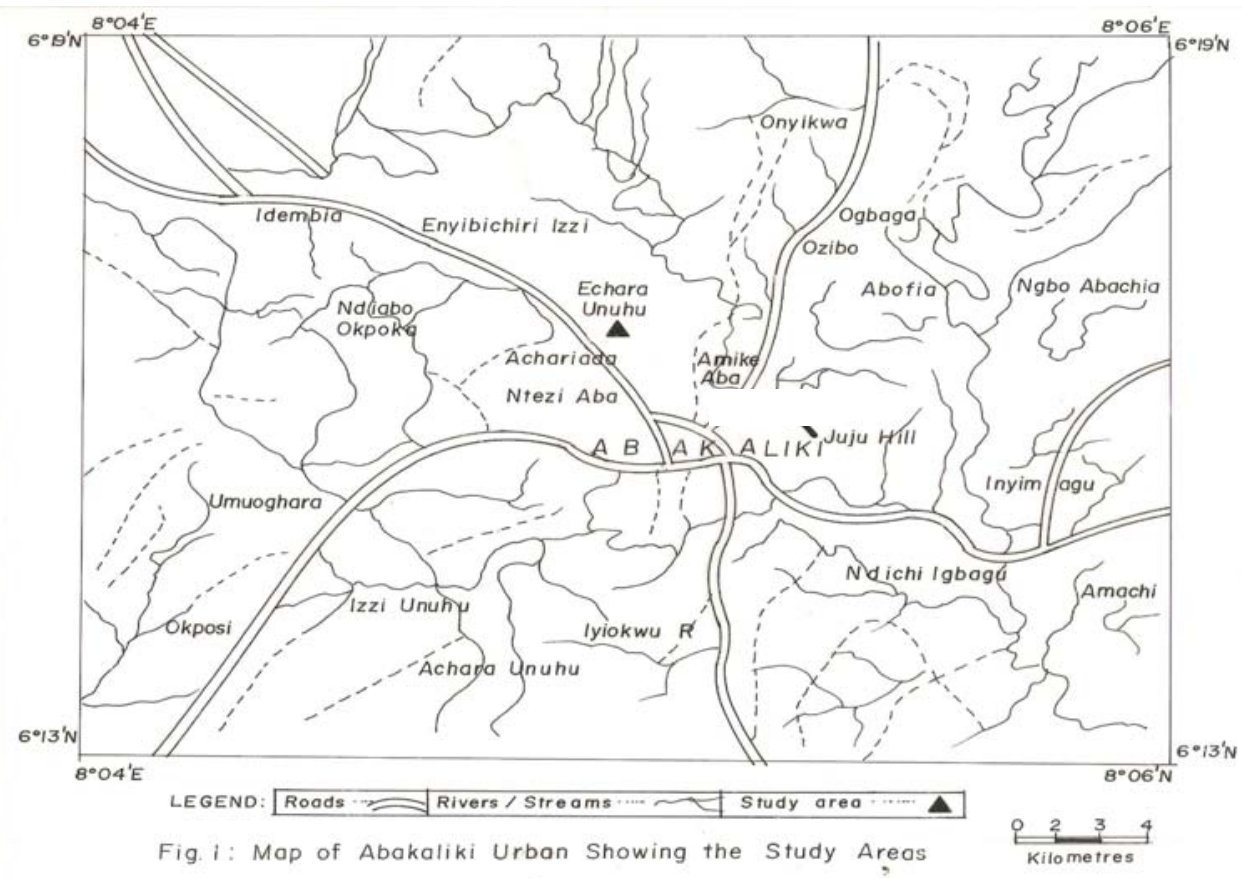

The application of geophysical methods in the study of Benue trough geology has centered mainly on mapping of regional structures of the trough using mainly gravity method (Artsbachev and Kogbe, 1974; Adighije, 1981a), aeromagnetic interpretation (Ofoegbu and Onuoha, 1991).Mamah et al (2000) and Ugwu (2006) used resistivity/magnetic and Spontaneous potential methods to study Lead-Zinc veins in Ishiagu and Abakaliki areas respectively.
The application of electromagnetic techniques to the measurement of terrain conductivity has been described (Keller and Frischnecht, 1966 and Wait, 1962). The purpose of this study is to use electromagnetic profiling to map the bedrock configuration in Echara Unuhu and possibly detect deeper fractures for groundwater development in this shale environment. 


\section{GEOLOGY OF ABAKALIKI}

The sequence of events that led to the formation of the Benue trough and its component units are now well documented ( Benkeliel, 1982; Ofoegbu, 1984). The lower Benue trough is underlain by a thick sedimentary sequence deposited in the Cretaceous. The Albian Abakaliki shales (Formation) is an inlier in the medial portion of the Abakaliki Basin. It is continuous for about $180 \mathrm{~km}$ stretching from Oju, north of the Workum hills in the northern part through Abakaliki to Lokpaukwu in the southern limit (Umeji, 2000). It is more or less spindle shaped with the broadest middle zone at Abakaliki up to $65 \mathrm{~km}$ across. The rocks are packages of thinly layered olive green to dark gray blush black shale, which are frequently calcareous, subordinate finegrained micaceous sandstone; micaceous siltstone, sandy shales and shelly limestone are present.

The sandstones are feldspathic (15\%), rock fragments mainly muscovite (3\%) and matrix

comprising clay and silt-size quartz mica, feldspars and heavy minerals (16\%) (Umeji,

2000). These sedimentary sequences were affected by large scale tectonic activities which occurred in two phases and culminated in the folding of the sediments. The predominant compressional nature of the folds that developed during this period is revealed by their asymmetry and the reverse faults associated with them (Ofoegbu and Onuoha, 1991). The development of Geology of Abakaliki occurred in a complete orogenic cycle including sedimentation, magmatism, metamorphism and compressive tectonics (Benkeliel, 1988).

\section{MATERIALS AND METHODS}

The major challenge was to ensure that the anomalies get will be due to the bedrock/fractures and not to the Lead and Zinc deposits prevalent in Echera Unuhu. Recourse was made to a priori information (API) which resolves non uniqueness (Zhadanov, 2002). API is defined as information not contained in the original equation (Menke, 1989) or as all other information beyond what we have chosen to call data (Jayne, 2003). In addition to field mapping, SP profiles were taken along the chosen traverses to delineate Lead and Zinc veins because an SP traverse over Lead and Zinc veins produces negative readings (Keary and Brooks,1998,Ugwu,2006).Geonics EM34-3 terrain conductivity meter was used in the data gathering.

Two traverses were taken

1. Total line length of the first profile was $520 \mathrm{~m}$ run in a direction normal to the strike and the inter-coil separation was $20 \mathrm{~m}$

\footnotetext{
* Corresponding author: Ugwu, S. A.
}

2. $600 \mathrm{~m}$ was the total line length of the second profile which also runs normal to the strike with the inter-coil separation retained as $20 \mathrm{~m}$.

The electromagnetic instrument measures terrain conductivity rather than resistivity. In profiling with the Geonics Em34-3 it is known that in a homogeneous or horizontally stratified earth, the current flow at any point in the ground is independent of the current flow at any other point since the magnetic coupling between all current loops is negligible and the depth of penetration is source or geometry limited rather than "skin depth" limited, because it is controlled by the fall off with the distance of the dipolar transmitter field (McNeil, 1980). The electromagnetic equipment measures the field strength and phase displacement around a fracture zone in the rock.

GEONICS EM34-3: This two-man portable equipment is based on the principle of electromagnetic induction. The time-varying magnetic field arising from alternating current in the transmitter coil induces very small currents in the earth. These currents generate a secondary magnetic field $\mathrm{H}_{\mathrm{S}}$ which is sensed, together; with the primary field, $\mathrm{H}_{\mathrm{P}}$, by the receiver coil. The secondary magnetic field is a complicated function of the inter coil spacing, s, the operating frequency, $f$, and the ground conductivity, $\sigma$.These are incorporated in EM 34-3 design (McNeill, 1980) whence,

$H_{S} / H_{P} \square i \omega \mu_{o} \sigma s^{2} / 4$

where $\mathrm{H}_{\mathrm{S}}=$ secondary magnetic field

$\mathrm{H}_{\mathrm{P}}=$ primary magnetic field at the receiver coil. $\omega=2 \pi f$

$f=$ frequency $(\mathrm{Hz})$

$\mu_{o}=$ permeability of free space (Darcy)

$\sigma=$ ground conductivity $(\mathrm{mmho} / \mathrm{m})$

$\mathrm{s}=$ intercoil spacing $(\mathrm{m})$

$i=\sqrt{-1}$

The apparent conductivity indicated by the instrument from (1) is, therefore

$$
\sigma_{a}=4 / \omega \mu_{o} s^{2}\left(H_{S} / H_{P}\right)
$$

A search coil is held horizontally (to measure the vertical component) and vertically (to measure the horizontal component). To measure the terrain conductivity the transmitter operator stops at the measurement station, the receiver's operator moves the receiver coil backwards or forwards until his meter indicates correct inter-coil spacing (in this case 
$20 \mathrm{~m})$. Then he reads the terrain conductivity from a second meter. Three different intercoil spacing are possible with Geonics Em34-3 equipment, 10m, 20m, and $40 \mathrm{~m}$, each operating at different frequency. McNeil (1980) showed that horizontal and vertical orientation of the equipment has different responses with depth. Barker (1992) calculated the depth of penetration for the three coil separations $(10 \mathrm{~m}, 20 \mathrm{~m}$ and $40 \mathrm{~m}$ ) as $3.7 \mathrm{~m}, 7.6 \mathrm{~m}$ and $15.2 \mathrm{~m}$ respectively for vertical coils and $8.7 \mathrm{~m}, 17.4 \mathrm{~m}$ and $34.8 \mathrm{~m}$ respectively for horizontal coils. The vertical coil reading gives information about the shallow zones while the horizontal coil penetrates deeper into the fractured zones.

\section{RESULTS AND DISCUSSION}

The results/data obtained (both vertical and horizontal coil resolutions) in conductivity $(\mathrm{mmho} / \mathrm{m})$ are plotted vertically against the distance (m) traversed in a horizontal direction. These results are presented in figures 2 and 3 . The typical conductivity value of the shallow bedrock (1.51-2.00m) (Fig.2)

PROFILE One

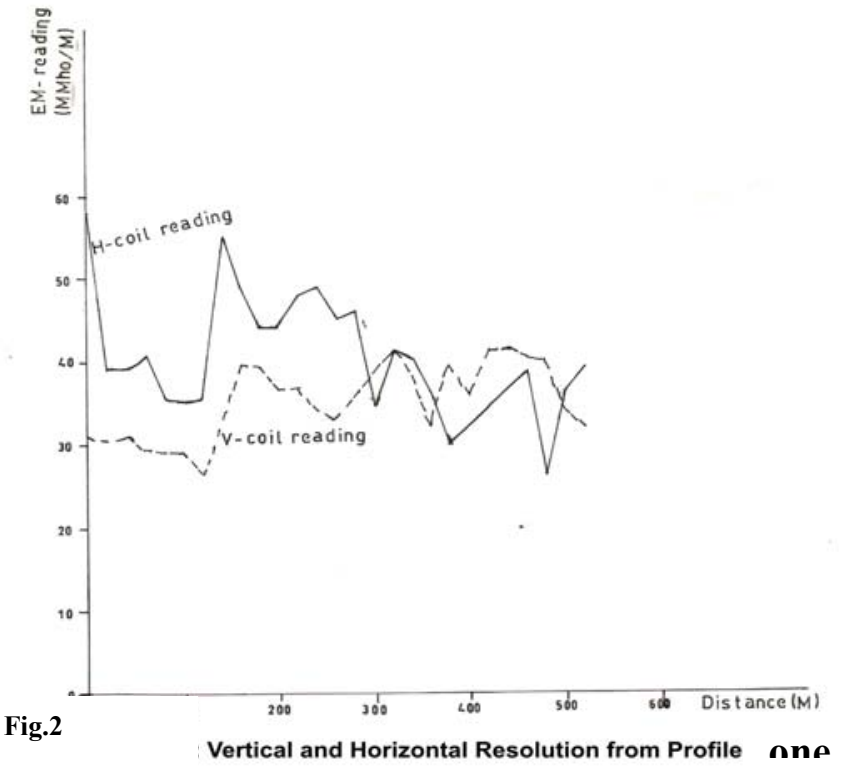

Fig 3 achieved both purposes and a borehole was recommended to be drilled between 20 and $120 \mathrm{~m}$ at a coordinate $007.96575 \mathrm{E}$ and $06.46623 \mathrm{~N}$. This was done and the borehole yields 20 liters of water per minute using hand pump.

Conclusion: The research has revealed the morphology of the bedrock in Echara Unuhu. The

* Corresponding author: Ugwu, S. A. lies between 22.1-53.7 $\mathrm{mmho} / \mathrm{m}$. This traverse (Fig.2) helps to determine the depth to the bedrock topography $(1.51-2.0 \mathrm{~m})$ where building foundation can be placed safely but too small a value both in depth/thickness and conductivity to help in groundwater development considered also to be essential to the people. Then a second profile was taken (Fig. 3). This figure demonstrates the configuration of the bedrock and the location of the deeper fractured shale (25.0-30.0m) with corresponding high conductivity values 269$786 \mathrm{mmohm} / \mathrm{m}$. From the distance $20-180 \mathrm{~m}$ there are high peaks with corresponding increase in conductivity values from 269-786mmohm $/ \mathrm{m}$ showing deeper fractures with high moisture contents while from $180-600 \mathrm{~m}$ the conductivity values fluctuate between $22.1-53.7 \mathrm{mmohm} / \mathrm{m}$ indicating shallow fractures $(1.51-2.0 \mathrm{~m})$ with low moisture content. Where the conductivity values did not change much the rock was generally not fractured (McNeil, 1980, Ugwu, 2009). The higher the peak the deeper the rock fractured.

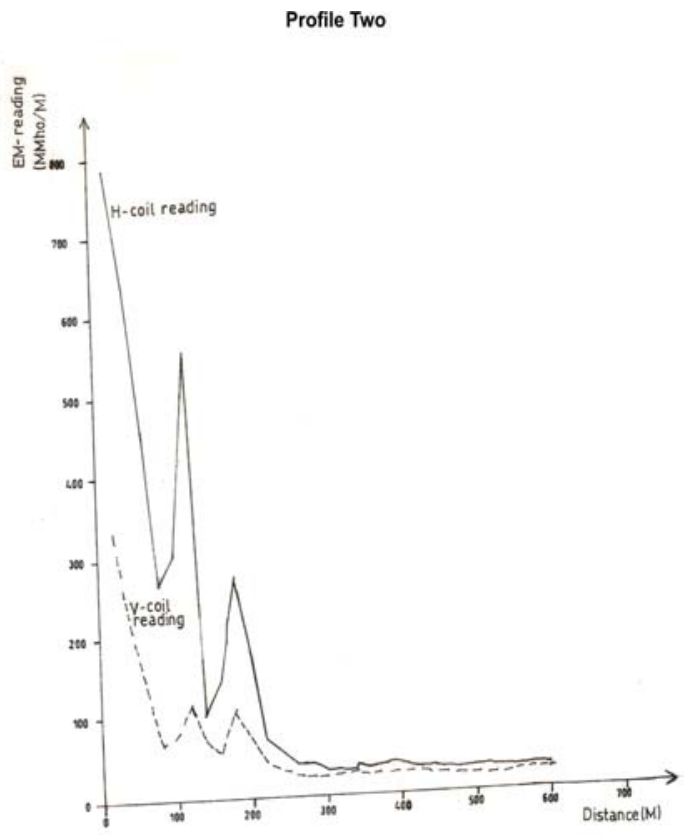

Fig 3

Vertical and Horizontal Resolutions from Profile 2

conductivity values for the shallow bedrock and the deeper fractured shales with much moisture content were equally determined. It has further thrown more light on differentiating conductivity from lead/zinc and that from bedrock/fractured shales and proved that water cannot be got everywhere in Echara Unuhu without proper studies. 


\section{REFERENCES}

Adighije, C; (1981a). Gravity Study of Lower Benue Trough, Nigeria. Geol. Mag., 118; 59-67.

Artsbachev, V A; Kogbe, C A (1974). Crustal structure of the Benue Valley area (Nigeria). Geol. Rundschau, 64, 324-329.

Barker, E B (1992). Em depth penetration. In McDonald and Davies 1998. Groundwater development maps for Oju and Obi Local Government Areas of Eastern Nigeria, Technical report WC/98/53. Overseas geological services.

Benkeliel, J (1982). Benue Trough (aulacogen) a tectonic model Geol. Mag. 112. 575-583.

Benkeliel, J (1988). Structure et evolution geodynamique de basis intercontinental de ca Benoue (Nigeria) Bull centres Rech. Explor Prod. ELF Aquaintaine 1207, 29-128.

Jaynes, E T (2003). Probability theory: The logic of sciences .Cambridge University Press

Keary, P; Brooks, M (1998).An Introduction to Geophysical Exploration. Second edition. Blackwell Science, Inc. pp. 253

Keller, G V; $\quad$ Frischknecht, F C (1966). Electrical methods in Geophysical Prospecting .Pergamon press

Mamah, L I.; Ezepue, M C; Ezeigbo, H I (2000). Integration of Geology and Geophysics in mineral Exploration in the Benue trough, Nigeria. The Onuahia Lead-zinc Deposit. A case study. Global J. Pure Appli. Sci.. 6 (2) 255262.
McDonald, E N; Davies, B R (1998). Groundwater development maps for Oju and Obi Local Government Areas Eastern Nigeria. Technical report $\mathrm{WC} / 98 / 53$ overseas geological services.

McNiell, J B (1980). Electrical conductivity of Soils and Rocks. Cambridge University Press, London pp. 180.

Menke, W (1989). Geophysical data analysis: Discrete inverse theory. Academic Press Inc.

Ofoegbu, C O (1984). Interpretation of aeromagnetic anomalies over the lower Benue trough, Nigeria Geophy. J.R. Astro. Soc. 79

Ofoegbu, C O; Onuoha, K M (1991). Analysis of magnetic Data over the Abakaliki Anticclnorium of the lower Benue trough Nigeria. J. Mar. Geol.. 45-51.

Ugwu, S A (2006). The use of Spontaneous Potential (SP) in mineral exploration in Benue trough Nigeria. J. Info. Co. Technol. (JICCO TECH) 2 (2)164-172

Ugwu S A (2009). Groundwater exploration in difficult terrains using an integrated geophysical approach. A case study of parts of Enugu state. World J. Sci. Technol .1(1) 59-67.

Umeji, A C (2000). Evolution of the Abakaliki and Anambra sedimentary basins southeastern Nigeria. A report submitted to the shell Petrol. Dev. Co. Nig Ltd 147.

Wait, J R (1962). A note on the electromagnetic Response of a stratified Earth. Geoph. 27, 382385.

Zhadanov, M S (2002). Geophysical inverse theory and regularization or Problems. Elsevier Science Pub. Co. Inc. 